\title{
Rehberlik Araştırma Merkezlerinde Yapılan Çalışmaların Gözden Geçirilmesi
}

\author{
Arş. Gör. Yunus YILMAZ \\ Anadolu Üniversitesi, Eğitim Fakültesi, Özel Eğitim Bölümü, Eskişehir / Türkiye, \\ yunus_yilmaz@anadolu.edu.tr, ORCID: 0000-0001-6988-798
}

Arş. Gör. Ahmet Serhat UÇAR*

Anadolu Üniversitesi, Eğitim Fakültesi, Özel Eğitim Bölümü, Eskişehir / Türkiye, asucar@anadolu.edu.tr, ORCID: 0000-0001-5910-8751

\section{$\ddot{O} z$}

Bu araştırmanın amacı 2003-2018 yılları arasında Rehberlik ve Araştırma Merkezlerinde (RAM) yürütülen araştırmaların tematik olarak incelenmesidir. Bu bağlamda çalışmaya dahil edilen araştırmalar; (a) özel eğitim süreçleriyle ilişkili olması (b) rehberlik ve araştırma merkezlerinden katılımcıların dâhil olması, (c) web yoluyla uzaktan erişime açı olması kriterleri göz önünde bulundurularak seçilmiştir. Bu kriterleri karşılayan 16 araştırmaya ulaşılmıştır. Bu çalışmaların 9'u yüksek lisans tezi, 7'si ise makaleden oluşmaktadır. Araştırmalar, nitel veri analizi yöntemlerinden içerik analizi aracılığıyla ana tema ve alt temalar altında toplanmıştır. Oluşturulan temalardan hareketle, fiziksel sorunlar, ölçme ve değerlendirme araçlarının kullanımı, paydaşlarla iş birliği, aile katılımı, RAM'ların genel işleyişi ve tanı, değerlendirme, yönlendirme, yerleştirme süreçleriyle ilgili sorunlar, RAM'larda materyal eksikliği, değerlendirme odalarının kullanışlı olmaması, binaların yetersizlik türlerine göre dizayn edilmeyişi, 1s1, 1şık, yalıtımın uygun olmayışı gibi birçok fiziksel sorun görülmektedir. Sonuç olarak RAM'larda işleyişi olumsuz etkileyen pek çok sorun bulunduğu ve işleyişin sorunsuz gerçekleştirilebilmesi için önemli iyileş̧irmelere gereksinim olduğu 
düşünülmektedir.

Anahtar Kelimeler: Rehberlik ve araştırma merkezi; Özel eğitim; Tanı; Değerlendirme; Yönlendirme; Yerleştirme.

\title{
Reviewing Studies at Guidance and Research Center
}

\begin{abstract}
The objective of this research is to thematically examine the studies conducted at Guidance and Research Centers (RAM) between 20032018. In this regard, the studies are included in this research by following the criteria whether a) it is related to special education process, b) it encompasses participants from the guidance and research centers, and c) it has an option for remote access via web. A total of 16 studies were found meeting the criteria stated above. 9 out of 16 studies are master's thesis and 7 of them are articles. The studies were clustered into main theme and sub-themes with the help of content analysis which is a qualitative data analysis. In line with the clustered themes, it becomes obvious that there are a number of physical problems including problems regarding the use of assessment and evaluation instruments, collaboration with stakeholders, family involvement, general functioning of RAMs and identification, evaluation, guidance, settlement process as well as physical problems such as a lack of material in RAMs, impractical evaluation rooms of RAMs, buildings not designed in accordance with failure types, and inappropriateness of temperature, light and isolation. As a consequence, it becomes clear that there are a number of problems affecting general functioning of RAMs negatively, and improvements are needed to provide smooth functioning in RAMs.
\end{abstract}

Keywords: Guidance and research center; Special education; Diagnose; Assesment; Guidance; Placement.

\section{Extended Summary}

\section{Purpose}

The objective of this research is to thematically examine the studies conducted at Guidance and Research Centers (RAM) between 2003-2018. It is thought that this research contributes to filling the gap in the literature by presenting the problems encountered during education process of disable individuals in RAMs, solution recommendations to these problems and improvements needed to raise the expectations and quality in a corpus-based. 


\section{Method}

The studies focusing on RAMs were categorized into three main themes which are a) processes, b) problems and c) demographic characteristics when analyzed thematically. There are also 15 sub-themes under three main themes. When analyzed in thematical terms, it was observed that the studies focus on processes in RAMs, the problems regarding this process, and the impact of demographic characteristics of RAM staff on the functioning. Under the theme "RAM processes", a total of six sub-themes such as screening, sending, identification, settlement, evaluation, and monitoring were constituted. When the studies conducted on screening process were analyzed, it revealed that screening was made twice a year (Kamen-Akkoyun, 2007) and it also became clear that screening was not sufficient and widespread (Avcioğlu, 2012). It is stated that the reports prepared by schools encompassing students' information and observations within the scope of sending process are submitted to RAMs. It is further stated that opinions are mostly received from families, and rarely from students in the identification process. Disability type and medical diagnosis, parent's opinion, expert's opinion, opinion of educational institution in which the students receive education, and the region of residence of the students are respectively taken into account in the settlement process. When the evaluation process is investigated, it is found that there are studies focusing on special education fields and processes, and also on the students having brain disabilities or developmental disabilities. There are also studies focusing solely on mathematics.

Under the theme "demographic characteristics", there are three sub-themes as managers, teachers and families. The impact of demographic characteristics of these stakeholders on RAM processes was scrutinized. In the studies conducted with RAM managers, no significant difference was found regarding their gender, working positions, seniority, undergraduate programs they graduate, whether they work as a proxy or a principal or they receive inservice training or not, their age, and their educational background (graduate) (Aydın, 2009; Tiryakioğlu, 2009). Similar results were also obtained from the teachers working in RAMs. Likewise, no significant difference was found regarding the teachers' gender, working positions, branches, educational background (graduate), seniority and age.

Under the "problems" theme, which is included in the last finding group, a total of seven sub-themes were constituted as families, RAM staff, 
budget, collaboration, forms/tests, the institution's functioning and physical conditions. It is indicated that families have a limited right to speak about identification, evaluation, and settlement process (Özak, Vural and Avcioğlu, 2008). It is also indicated that a qualified staff is limited in numbers in RAMs (Ekim, 2015; Güven ve Balat, 2006; Kamen-Akkoyun, 2007; Tiryakioğlu, 2009; Yurtsever, 2013) and they do not receive training regarding the tests to be applied in the evaluation process (Börkan, Öztemur, Yılmaz, Çetintaş, Gülcan and Özcan 2017; Yurtsever, 2013).

When the problems related to the sub-theme "budget" are examined, it is seen that the primary need is a vehicle requested to be put at the disposal of RAM in order to be able to carry out evaluation and monitoring process (Kamen-Akkoyun, 2007; Y1lmaz, 2016). It is also found that there is no collaboration between hospitals and RAM.

\section{Results, Discussion and Conclusion}

When the studies conducted on special education are examined in terms of its participants, it becomes clear that almost all of them (13) were carried out with teachers. Most of these participants are composed of special education teachers, and rest of them are advisory teachers. When the studies are examined in line with their objectives, physical problems as well as problems related to the use of assessment and evaluation instruments, collaboration with stakeholders, family involvement, general functioning of RAMs and identification, evaluation, guidance and settlement processes have been revealed. Apart from these objectives, there are limited studies focusing on harmonization activities of RAMs, and duties and responsibilities of BEP (Individualized Education Program). When the methods applied in the studies are examined, it is found that all studies used descriptive methods. It is further observed that qualitative and quantitative methods were preferred equally. When the studies are examined in terms of their findings, it can be stated that there are a variety of physical problems such as a lack of materials in RAMs, impractical evaluation rooms, buildings not designed in accordance with failure types, and inappropriateness of temperature, light and isolation. The problems need to be solved so that RAMs could fulfill the activities of screening, educational identification, monitoring, evaluation and settlement given by Guidance Service Regulation (2017). In this regard, it might be suggested that active participation of stakeholders and in-service training organized for RAM staff in line with their needs could be provided by improving physical conditions of 
RAMs, correcting the staff's deficiencies, providing assessment and evaluation instruments with current validity and credibility, and developing collaboration between stakeholders. In a nutshell, there are a variety of studies conducted on RAMs, which play a crucial role in special education process in our country. Even though the number of studies is limited, they generally point out similar problems. Thus, these findings indicate that there is a need for new studies that will help to solve the problems and to correct the deficiencies, aim to directly intervene in the system and include practice in it. Although this research puts forward important data regarding the studies conducted on special education in RAMs, it has some limitations. The selected studies focus on special education in RAMs and include RAM staff as participants. Examination measurements determined for revision of the studies might lead to departure from objectivity, and they mostly inform the reader regarding the study in general terms (Kavale, 2001). Thus, limited dataflow is provided in line with examination measurements in this study.

\section{Giriş}

Özel eğitim gereksinimi olan bireylerin eğitimlerine başlayıp sürdürebilmeleri için yasa ve yönetmeliklerle belirlenmiş süreçlerden geçmeleri gerekmektedir (Ceyhan, Akdoğan ve Bozkurt, 2013). Bu süreçler tarama, gönderme, tanılama, sınıflama, değerlendirme, yönlendirme, yerleştirme ve izleme şeklinde sıralanmaktadır (Çuhadar, 2014; Gürsel, 2013). Milli Eğitim Bakanlığı, Özel Eğitim Hizmetleri Yönetmeliği'nde belirlenen unsurları hayata geçirme ve yürütme kurumları arasında RAM'lar da yer almaktadır (Güven ve Balat, 2006). RAM'lar bu süreçte tarama, eğitsel tanılama, izleme, değerlendirme ve yerleştirme adımlarında aktif rol oynamaktadır (Rehberlik Hizmetleri Yönetmeliği, 2017). Dolayısıyla RAM'ın işleyişinin taramadan, izlemeye tüm süreçleri doğrudan ya da dolaylı olarak etkileyebileceği düşünülebilir. Sayıları az olsa da alanyazında, RAM'lardaki tanı, değerlendirme, yönlendirme, yerleştirme, izleme gibi süreç odaklı ya da stres, çalışma yaşamı kalitesi, öz yeterlilik, tutum, kuruma bağlılık, yönetim stilleri gibi idareci veya personel odaklı çalışmalar bulunmaktadır (Aslan ve Bal, 2014; Avcıoğlu, 2012; Gürbüz, 2012; Karaköse ve Bozgeyikli, 2012; Özgözgü, 2011; Yanık ve Gürgür, 2017). Ancak alanyazın incelendiğinde RAM'lara ilişkin derleme çalışmasına rastlanmamaktadır. RAM'larda özel gereksinimli bireylerin eğitimine yönelik yürütülen süreçlerde yaşanan sorunları, bu sorunlara yönelik çözüm önerileri, beklentileri ve niteliği arttırmak adına yapılması beklenen iyileştirme çalışmalarını bütüncül bir bakış açısıyla sunmanın alanyazındaki 
bu boşluğu gidereceği düşünülmektedir.

\section{Yöntem}

\section{Araștırma Modeli}

Araştırmada 2003-2018 yılları arasında RAM'larda eğitim bilimleri alanında yapılmış çalışmalar tematik olarak derlenmiştir. Belli bir alanda gerçekleştirilen araştırmaların konu kronoloji gibi çeşitli bağlamlarda incelendiği bir araştırma türü olan derleme araştırmaları okuyucuya ilgili alanda bilgi verme, güçlü ve zayıf yönlerini ortaya koyma işlevinin yanı sıra yeni araştırmalara da zemin hazırlamaktadır. (Creswell, 2013; Herdman, 2006).

\section{Veri Toplama Araçları}

Bu araştırmada RAM'larda yürütülen çalışmalara Yüksek Öğretim Kurumu (YÖK) Ulusal Tez Merkezi, Google Scholar, EBSCO-Host, Web of Science, Ulusal Akademik A $\breve{g}$ ve Bilgi Merkezi (ULAKBİM) veri tabanları kullanılmıştır. Veri tabanlarında Türkçe olarak "rehberlik", "araştırma merkezi", "eğitsel tanı", "değerlendirme", "eğitsel değerlendirme" ve "izleme" kelimeleri birlikte ya da tekil, Türkçe ve İngilizce olarak aratılarak konuya ilişkin gerçekleştirilen çalışmalara ulaşılmıştır.

\section{Veri Toplanması ve Analizi}

Yapılan tarama sonucunda 24 çalışmaya ulaşılmıştır. Ölçüt örnekleme kullanılarak gerçekleştirilen çalışmaların; (a) doğrudan rehberlik ve araştırma merkezleriyle ilişkili olması, (b) web yoluyla uzaktan erişime açık olması kriterleri kullanılmış, bu ölçütleri karşılayan 16 çalışma araştırmada yer almıştır. Dört çalışma doğrudan RAM çalışanlarıyla veri toplamaması, farklı bir çalışmadaki verileri güçlendirmek için RAM personelinden bilgi alınması ve herhangi bir katılımcı olmaksızın sadece eski tarihte RAM'a gelen başvuruları incelemesi nedenleriyle araştırmaya dahil edilmemiştir. Araştırmaya dahil edilen 16 çalışmanın 9'u yüksek lisans tezi iken 7'si makale olarak yayınlanmıştır. Yayınlanan araştırmalar nitel veri analizi yöntemlerinden içerik analizi kullanılarak ele aldıkları konulara göre ana temalara ve alt temalara ayrılmıştı. Araştırmacı tüm çalışmaları detaylı şekilde okuyarak konulara göre kodlama yapmıştır. Akabinde benzer kodları bir araya getirerek ana ve alt temalara ulaşmıştır. Nitel araştırma yöntemlerinde uzman bir öğretim üyesi ise hem kodlama sürecinde hem de tema oluşturma sürecinde görüşlerini sunmuştur. Süreç sonunda ortaya çıkan tema ve alt temaları gösteren Tablo 1'de verilmiştir. 
Tablo 1. Tema ve Alt Temalar

\begin{tabular}{ll}
\hline Temalar & Alt Temalar \\
\hline Tema 1: RAM Süreçleri & Tarama \\
& Gönderme \\
& Tanılama \\
& Yerleştirme \\
& Değerlendirme Süreci \\
\hline Tema 2: Demografik Özellikler & İdareciler \\
& Öğretmenler \\
& Aileler \\
\hline Tema 3: Sorunlar & Aileler \\
& RAM Personeli \\
& Bütçe \\
& İş birliği \\
& Formlar/Testler \\
& Kurum İşleyişi \\
& Fizikî Şartlar \\
\hline
\end{tabular}

\section{Bulgular}

Analizler sonucu araştırmaya dahil edilen 16 çalışma araştırma yöntemlerine göre sınıflandırılmıştır. Nicel, nitel ve karma yöntemle yürütülen araştırmalar amaç, katılımcılar ve özet bulguları Tablo 2, Tablo 3 ve Tablo 4'te özetlenmiştir.

Analizler sonrası RAM'larda özel eğitimle ilişkili yedi nicel çalışmaya ulaşılmaktadır. Nicel çalışmaların 2006-2013 yı1ları arasında gerçekleştiği görülmektedir. Çalışmaların üçü yüksek lisans tez çalışması, dördü ise makaledir. Bu çalışmalar incelendiğinde iki çalışmanın RAM yöneticileriyle yürütüldüğü, iki çalışmanın yönetici olmayan RAM çalışanlarıyla yapıldığı, bir çalışmanın yönetici ve çalışanlarla birlikte yapıldığı, iki çalışmaya ise okullarda görev yapan öğretmenlere ek olarak RAM çalışanlarının katıldığı görülmektedir. Dolayısıyla araştırmacıların RAM yöneticileri ya da çalışanlarına ilişkin bir seçicilik göstermediği ifade edilebilir. RAM'larda yürütülen tüm nicel çalışmalarda betimsel analizlerin kullanıldığı görülmektedir. Çalışmaların dördünde ölçek üçünde anket kullanılmıştır.

Araştırmaların yoğunlaştığı konular incelendiğinde ise tanı, değerlendirme, yönlendirme, yerleştirme, izleme süreçlerinde yaşanan sorunlar, BEP'e yönelik tutumlar ve karş1laşılan zorluklar, kaynaştırma sürecine ilişkin görüşler ve yaşanılan zorluklar, özel eğitim bölümünün sorunları çevresinde toplandığı görülmektedir. 


\section{Tablo 2. Araştırmaya Dahil Olan Nicel Araştırmalara İlişkin Özellikler}

\begin{tabular}{|c|c|c|c|}
\hline Kaynak & Araştırmanın Amacı & Yöntem & Katılımcılar ve Özellikleri \\
\hline $\begin{array}{l}\text { Güven ve Balat, } \\
(2006)\end{array}$ & $\begin{array}{l}\text { Özel eğitim gereksinimi olan çocukların } \\
\text { kaynaştırıldığı ilköğretim okullarında gö- } \\
\text { rev yapan rehber öğretmenler ile RAM ça- } \\
\text { lışanlarının kaynaştırma sürecine ilişkin } \\
\text { görüşlerinin alınması. }\end{array}$ & $\begin{array}{l}\text { Nicel araştırma } \\
\text { (Makale) }\end{array}$ & $\begin{array}{l}\text { İstanbul'da görev yapan } 138 \\
\text { rehber ögrretmen ve } 79 \text { RAM } \\
\text { personeli }\end{array}$ \\
\hline $\begin{array}{l}\text { Tiryakioğlu, } \\
(2009)\end{array}$ & $\begin{array}{l}\text { RAM Özel Eğitim Hizmetleri Bö- } \\
\text { lümü'nün sorunlarının ve bu sorunlarla } \\
\text { ilişkili değişkenlerin belirlenmesi. }\end{array}$ & $\begin{array}{l}\text { Nicel araştırma } \\
\text { (Yüksek Lisans Tezi) }\end{array}$ & $\begin{array}{l}\text { Ülke genelinde görev yapan } \\
110 \text { RAM müdürü }\end{array}$ \\
\hline $\begin{array}{l}\text { Aydın, } \\
(2009)\end{array}$ & $\begin{array}{l}\text { RAM yönetici ve öğretmenlerinin kaynaş- } \\
\text { tırma eğitimine yönelik tutumlarının de- } \\
\text { ğerlendirilmesi. }\end{array}$ & $\begin{array}{l}\text { Nicel araştırma } \\
\text { (Yüksek Lisans tezi) }\end{array}$ & $\begin{array}{l}\text { İstanbul ilindeki RAM'larda } \\
\text { görev yapan toplam } 208 \\
\text { RAM personeli ve yönetici }\end{array}$ \\
\hline $\begin{array}{l}\text { Yurtsever, } \\
(2013)\end{array}$ & $\begin{array}{l}\text { Eğitsel tanılama ve değerlendirme süre- } \\
\text { cinde görev alan RAM personelinin karş1- } \\
\text { laştığ1 sorunların belirlenmesi. }\end{array}$ & $\begin{array}{l}\text { Nicel araştırma } \\
\text { (Yüksek Lisans Tezi) }\end{array}$ & $\begin{array}{l}\text { İstanbul ilinde görev yapan } \\
145 \text { RAM personeli }\end{array}$ \\
\hline $\begin{array}{l}\text { Avcioğlu, } \\
(2012)\end{array}$ & $\begin{array}{l}\text { RAM müdürlerinin; tanılama, yerleştirme, } \\
\text { izleme, BEP geliştirme ve kaynaştırma } \\
\text { uygulamasında karşılaşılan sorunlara iliş- } \\
\text { kin görüşlerinin belirlenmesi. }\end{array}$ & $\begin{array}{l}\text { Nicel araştırma } \\
\text { (Makale) }\end{array}$ & 116 RAM müdürü \\
\hline $\begin{array}{l}\text { Tike-Bafra ve } \\
\text { Kargın, (2009) }\end{array}$ & $\begin{array}{l}\text { İlköğretim okulu öğretmenlerinin, okul } \\
\text { psikologlarının ve RAM personelinin bi- } \\
\text { reyselleştirilmiş bir eğitim programı sü- } \\
\text { reci geliştirme konusundaki tutumlarını ve } \\
\text { bu süreçte karşılaşılan zorlukları çeşitli } \\
\text { değişkenlere göre analiz edilmesi }\end{array}$ & $\begin{array}{l}\text { Nicel araştırma } \\
\text { (Makale) }\end{array}$ & $\begin{array}{l}42 \text { RAM personeli, } 159 \text { öğ- } \\
\text { retmen (ilkokul öğretmeni, } \\
\text { okul psikoloğu, özel eğitim } \\
\text { öğretmeni) }\end{array}$ \\
\hline $\begin{array}{l}\text { Gürbüz ve Boz- } \\
\text { geyikli, (2014) }\end{array}$ & $\begin{array}{l}\text { RAM'larda çalışan rehber öğretmenlerin, } \\
\text { özel eğitimde rehberlik ve psikolojik da- } \\
\text { nışmaya yönelik öz yeterlik algıları çeşitli } \\
\text { değişkenlere göre incelenmesi. }\end{array}$ & $\begin{array}{l}\text { Nicel araştırma } \\
\text { (Makale) }\end{array}$ & $\begin{array}{l}35 \text { ildeki RAM'larda görev } \\
\text { yapan } 254 \text { rehber öğretmen }\end{array}$ \\
\hline
\end{tabular}


Kalem Eğitim ve İnsan Bilimleri Dergisi 2021, 11(2), 513-533

\section{Tablo 3. Araştırmaya Dahil Olan Nitel Araştırmalara İlişkin Özellikler}

\begin{tabular}{|c|c|c|c|}
\hline Kaynak & Araştırmanın Amacı & Yöntem & Katılımcılar ve Özellikler \\
\hline $\begin{array}{l}\text { Özak, } \\
\text { Vural ve } \\
\text { Avcioğlu, (2008) }\end{array}$ & $\begin{array}{l}\text { RAM müdürlerinin gönderme, tanılama, yerleş- } \\
\text { tirme, izleme ve değerlendirmeye yönelik görüşleri } \\
\text { ve önerilerinin belirlemesi. }\end{array}$ & $\begin{array}{l}\text { Nitel araş- } \\
\text { tırma } \\
\text { (Makale) }\end{array}$ & $\begin{array}{l}2005 \text { yllında Mersin hizme } \\
\text { eğitim kursuna katılan } 6 \mathrm{R} \\
\text { müdürü }\end{array}$ \\
\hline $\begin{array}{l}\text { Marakl1, } \\
(2016)\end{array}$ & $\begin{array}{l}\text { RAM'da görev yapan özel eğitim öğretmenlerinin } \\
\text { eğitsel değerlendirme ve yerleştirmeye bağlı olarak } \\
\text { kullanılan modül programlarının uygulanması hak- } \\
\text { kındaki görüşlerinin incelenmesi. }\end{array}$ & $\begin{array}{l}\text { Nitel araş- } \\
\text { tırma } \\
\text { (Yüksek } \\
\text { Lisans Tezi) }\end{array}$ & $\begin{array}{l}\text { Ankara ilindeki } 5 \text { farklı } \\
\text { RAM'da görev yapan } 20 \text { ö } \\
\text { eğitim öğretmeni }\end{array}$ \\
\hline $\begin{array}{l}\text { Çakmak, } \\
(2017)\end{array}$ & $\begin{array}{l}\text { Öğrenme güçlüğü olan bireylerin fark edilme ve } \\
\text { eğitsel tanılama süreçlerine ilişkin RAM personelle- } \\
\text { rinin görüş ve önerilerinin belirlenmesi. }\end{array}$ & $\begin{array}{l}\text { Nitel araş- } \\
\text { tırma } \\
\text { (Yüksek } \\
\text { Lisans Tezi) }\end{array}$ & $\begin{array}{l}\text { Eskişehir ilinde görev yapa } \\
12 \text { RAM personeli }\end{array}$ \\
\hline $\begin{array}{l}\text { Türkkal, } \\
\text { (2018) }\end{array}$ & $\begin{array}{l}\text { RAM personelinin, sınıflarında kaynaştırma öğren- } \\
\text { cisi bulunan ilkokul sınıf öğretmenlerinin ve mate- } \\
\text { matik becerilerinde yetersizlik yaşadığı için kaynaş- } \\
\text { tırma eğitimi alan öğrencilerin velilerinin, } \\
\text { RAM'daki eğitsel değerlendirme ve tanılama süreç- } \\
\text { lerine ilişkin görüşlerinin belirlenmesi. }\end{array}$ & $\begin{array}{l}\text { Nitel araş- } \\
\text { tırma } \\
\text { (Yüksek } \\
\text { Lisans Tezi) }\end{array}$ & $\begin{array}{l}7 \text { RAM personeli, RAM'a } \\
\text { renci yönlendiren } 7 \text { öğretm } \\
\text { ve matematiğe yönelik } \\
\text { RAM'dan hizmet alan } 7 \text { ve }\end{array}$ \\
\hline $\begin{array}{l}\text { Yanık, } \\
\text { Gürgür, } \\
\text { (2017) }\end{array}$ & $\begin{array}{l}\text { İşitme kaybi olan öğrencilerin kaynaştırma uygula- } \\
\text { malarına yönlendirilmesinde RAM prosedürlerinin } \\
\text { incelenmesi. }\end{array}$ & $\begin{array}{l}\text { Nitel } \\
\text { araştırma } \\
\text { (Makale) }\end{array}$ & $\begin{array}{l}14 \text { RAM personeli ve } 6 \mathrm{eb} \\
\text { veyn }\end{array}$ \\
\hline $\begin{array}{l}\text { Yilmaz, } \\
(2016)\end{array}$ & $\begin{array}{l}\text { İşitme kayıplı çocukların RAM'larda tanı, değerlen- } \\
\text { dirme ve izleme süreçlerinin incelenmesi. }\end{array}$ & $\begin{array}{l}\text { Nitel } \\
\text { araştırma } \\
\text { (Yüksek } \\
\text { Lisans Tezi) }\end{array}$ & $\begin{array}{l}\text { Eskişehir ilindeki RAM'la } \\
\text { çalışan } 13 \text { ögretmen }\end{array}$ \\
\hline $\begin{array}{l}\text { Börkan vd., } \\
(2017)\end{array}$ & $\begin{array}{l}\text { Türkiye'deki RAM'da çalışan psikolojik danışman- } \\
\text { ların test uygulamalarına yönelik deneyimlerinin } \\
\text { keşfedilmesi ve elde edilen bulguların Uluslararası } \\
\text { Test Komisyonu'nun (ITC) kılavuzu çerçevesinde } \\
\text { ortaya konulması }\end{array}$ & $\begin{array}{l}\text { Nitel } \\
\text { araştırma } \\
\text { (Makale) }\end{array}$ & $\begin{array}{l}\text { RAM'da çalışan } 20 \text { rehbe } \\
\text { retmen }\end{array}$ \\
\hline
\end{tabular}


Tablo 4. Araştırmaya Dahil Olan Karma Yöntem Araştırmalara İlişkin Özellikler

\begin{tabular}{|c|c|c|c|c|}
\hline Kaynak & Araştırmanın Amacı & Yöntem & $\begin{array}{l}\text { Katılımcılar ve } \\
\text { Özellikleri }\end{array}$ & Özet Bulgu \\
\hline $\begin{array}{l}\text { Ekim, } \\
\text { (2015) }\end{array}$ & $\begin{array}{l}\text { RAM'ların psikolojik } \\
\text { danışmanlık ve rehber- } \\
\text { lik bölümlerinin sun- } \\
\text { duğu hizmetlerin ince- } \\
\text { lenmesi. }\end{array}$ & $\begin{array}{l}\text { Karma yön- } \\
\text { tem araştır- } \\
\text { ması } \\
\text { (Yüksek } \\
\text { Lisans } \\
\text { Tezi) }\end{array}$ & $\begin{array}{l}\text { İzmir ilinde } \\
\text { Nitel adım için; } \\
\text { RAM'da çalışan } \\
5 \text { rehber öğret- } \\
\text { men, okulda çalı- } \\
\text { şan } 10 \text { rehber öğ- } \\
\text { retmen } \\
\text { Nicel adım için; } \\
\text { RAM'da çalı̧san } \\
16 \text { rehber ögret- } \\
\text { men }\end{array}$ & $\begin{array}{l}\text { RAM'ların fiziksel özel- } \\
\text { liklerinin, sayısının, büt- } \\
\text { çesinin, konumunun ve } \\
\text { RAM ile ilgili yönetme- } \\
\text { liklerin yetersiz olmas } \\
\text { nedeniyle süreci olumsuz } \\
\text { etkilediği olduğu ortaya } \\
\text { konmuştur. }\end{array}$ \\
\hline $\begin{array}{l}\text { Kamen- } \\
\text { Akkoyun, } \\
\text { (2007) }\end{array}$ & $\begin{array}{l}\text { Batı Karadeniz Bölge- } \\
\text { sinde bulunan } \\
\text { RAM'larda görev yap- } \\
\text { makta olan personelin } \\
\text { kaynaştırma eğitimine } \\
\text { ilişkin görüşlerinin be- } \\
\text { lirlenmesi }\end{array}$ & $\begin{array}{l}\text { Nitel } \\
+ \\
\text { Nicel } \\
\text { araştırma } \\
\text { (Yüksek } \\
\text { Lisans } \\
\text { Tezi) } \\
\end{array}$ & $\begin{array}{lr}\text { Batı } & \text { Karadeniz } \\
\text { Bölgesindeki } 7 \text { il } \\
\text { ve } 1 \text { ilçe } \\
\text { RAM'da görev } \\
\text { yapan } 13 \text { yöne- } \\
\text { tici ve } 22 \text { rehber } \\
\text { öğretmen } \\
\end{array}$ & $\begin{array}{l}\text { RAM çalışanlarının kay- } \\
\text { naştırmaya ilişkin bilgile- } \\
\text { rinin yeterli olduğu ancak } \\
\text { uygulamaya ilişkin so- } \\
\text { runların olduğu görül- } \\
\text { mektedir. }\end{array}$ \\
\hline
\end{tabular}

Alanyazın incelendiğinde RAM'larda özel eğitime ilişkin yedi nitel çalışmaya ulaşılmıştır. Çalışmaların 2008-2018 yılları arasında yapıldığı görülmektedir. Nitel çalışmalara ilişkin dikkat çekici bulgu ise altı araştırmanın 2016 yılı ve sonrasında yapılmış olmasıdır. Araştırmaların dördü yüksek lisans tezi, üçü ise makaledir.

Katılımcılar incelendiğinde bir çalışmanın yöneticilerle, üç çalışmanın özel eğitim öğretmenleriyle, bir çalışmanın psikolojik danışmanlarla, iki çalışmanın ise hem öğretmenler hem de velilerin katılımıyla yürütüldügü görülmektedir. Kısaca nitel çalışmalar ağırlıklı olarak öğretmenlerin katılımıyla gerçekleşmiştir.

Nitel çalışmalar konularına göre incelendiğinde fark etme, gönderme, tan1, değerlendirme, yerleştirme, izleme süreçlerine ilişkin görüşlerin belirlenmesi, değerlendirmelerde kullanılan modül programlarının içeriği, kaynaştırma uygulamalarına yönlendirme prosedürleri, RAM'lardaki test uygulamalarına yönelik deneyimlerin keşfedilmesi şeklinde amaçlarla karşılaşılmaktadir.

Alanyazın incelendiğinde RAM'larda özel eğitime ilişkin yapılmış bir karma çalışmaya ulaşılmıştır. Tablo 4 'te aktarıldığ gibi bir çalışmada karma yöntem kullanılmamış ancak hem nicel hem nitel yöntem kullanılmıştır. Karma yöntem kullanılan araştırmaya RAM'da ve okullarda çalışan rehber öğretmenler katılımcı olarak dahil edilmiştir. Diğer çalışmada ise rehber 
öğretmenlere ek olarak yöneticiler de çalışmada katılımcı olarak yer almıştır.

Her iki çalışma da yüksek lisans tezidir. Ek olarak araştırmaların nicel adımlarında anket formları ve ölçekler kullanılırken nitel adımlarında görüşmeler gerçekleştirilmiştir. Konular bazında çalışmalar incelendiğinde psikolojik danışmanlık ve rehberlik bölümlerinin sunduğu hizmetlerin incelendiği ve RAM personelinin kaynaştırmaya ilişkin görüşlerinin belirlendiği görülmektedir.

\section{Temalar}

RAM'larla ilgili araştırmalar tematik olarak analiz edildiğinde (a) süreçler, (b) sorunlar ve (c) demografik özellikler şeklinde üç ana temaya ayrılmıştır. Üç ana tema altında ise 15 alt temaya ulaşılmıştır. Temalardan yola çıkarak araştırmaların RAM'da işleyen süreçlere, bu süreçlere ilişkin yaşanan sorunlara ve RAM çalışanlarının demografik özelliklerinin işleyiş̧e etkisine odaklandığı görülmektedir.

\section{RAM Süreçleri}

RAM süreçleri teması kapsamında tarama, gönderme, tanılama, yerleştirme, değerlendirme ve izleme olarak altı alt temaya ulaşılmıştır.

Tarama sürecine ilişkin araştırmalar incelendiğinde tarama çalışmalarının y1lda iki defa yapıldığı (Kamen-Akkoyun, 2007) ve aksi yönde bir bulgu olarak taramaların yetersiz olduğu ve yaygın olmadığı (Avcığlu, 2012) bulgularına ulaşılmıştır. Bu sürece yönelik aynı kurum çalışanlarının 52.7'sine göre tarama çalışalarının yapıldığı, \%32.7'sine göre ise yapılmadığ 1 (Tiryakioğlu, 2009) şeklinde bulgu dahi görülmektedir. Ek olarak Çakmak (2017)'deki araştırmasında öğrenme güçlüğü olan bireylere yönelik tarama araçlarının geliştirilmesi gerektiğini aktarmıştır. Yurtsever (2013) ise tarama faaliyetini RAM'ların istenildiği ölçüde gerçekleştirmediğini aktarmıştır.

Gönderme süreci kapsamında okullar tarafindan hazırlanan öğrenci bilgi ve gözlemlerini içeren raporların RAM'a gönderildiği aktarılmaktadır. $\mathrm{Bu}$ raporların içeriğinde kaba değerlendirmeye ek olarak öğretmenler ve ailenin görüşleri bulunmaktadır. Ancak ifade edilen raporların içeriği kurumlar arasında farklılık göstermektedir (Özak, Vural ve Avcıŏlu, 2008). Ayrıca RAM'a gelen bu dosyaların yüzeysel, eksik ya da yanlış bilgiler içerebildiği, öğretmenlerin gönderme öncesi öğretimsel uyarlamaları yapmadıkları da görülmektedir. Öğretmenlerin gönderme sürecine ilişkin bilgi eksiklikleri, okulRAM iletişiminin yetersiz olması ise bu sorunların öncüsü olarak 
görülmektedir (Çakmak, 2017; Yurtsever, 2013).

Tanılama sürecinde, daha çok ailelerden görüş alındığı nadiren ise öğrencilerden görüş alındığı belirtilmiştir. Kararın ise öğrenci raporları içindeki öğretmen görüşleri, aile görüşleri ve RAM'da uygulanan standart testlerle verildiği ifade edilmektedir (Özak, Vural ve Avcıoğlu, 2008; Yılmaz, 2016). Aynı çalışmadaki bulgular incelendiğinde katılımcıların \%39.1'i eğitsel tanı için oluşturulan ekibin ihtiyaç duyulan alanlardaki uzmanlardan oluştuğunu, \%45.5'i ise oluşmadığını aktarmıştır (Tiryakioğlu, 2009). Ek olarak RAM'daki eğitsel tanı ile sağlık kuruluşundaki tıbbi tanının uyuşmadığı bulgusu görülmektedir (Çakmak, 2017; Yurtsever, 2013). Araştırmalar farklı dil ya da lehçe kullanan bireylerde tanılama sürecinde problemler yaşandığını da göstermektedir (Yurtsever, 2013; Y1lmaz, 2016). Son olarak tan1 sonras1 ailelere yeterli bilginin aktarılmadığı anlaşılmaktadır (Avcıŏglu, 2012).

Yerleştirme sürecinde sırasıyla yetersizlik türü ve tıbbi tanı, veli görüşü, uzman görüşü, öğrencinin devam ettiği eğitim kurumunun görüşü, ikamet ettiği bölge dikkate alınmaktadır. Yerleştirme sürecinde, özel eğitim sınıflarının ve özel alt sınıflarda çalışan personelin yetersiz olduğu, daha çok kaynaştırmanın tercih edildiği, materyal temini, personel istihdamı sağlanması gerektiği ifade edilmiştir (Özak, Vural ve Avcıoğlu 2008; Yılmaz, 2016; Yurtsever, 2013). Araştırma kapsamındaki çalışmaların bir tanesinde katılımcıların \%47.4'ünün kaynaştırma sınıfına yerleştirme kararı alınırken sınıf öğretmeninden görüş alındığ1 \%34.6'sının ise herhangi bir görüşe başvurmadan kaynaştırma sınıfına yerleştirildiği belirtilmiştir. Bu bulguya dayanarak yerleştirmeye ilişkin de RAM çalışanlarının bakış açılarında farklılık olduğu söylenebilir. Bunun yanı sıra bir araştırma bulgusunda destek hizmetlerin sağlanmadığ1 vurgulanmaktadır (Tiryakioğlu, 2009). Kaynaştırma eğitimine ilişkin RAM'da çalışan rehber öğretmen ve idarecilerin bilgisinin ise yeterli olduğu aktarılmaktadır (Kamen-Akkoyun, 2007). Ancak bu konuda zit bulgular da alanyazında yer almaktadır. Okullarda çalışan rehber öğretmenler kaynaştırma konusunda kendilerini RAM çalışanlarına göre daha yetersiz görmektedir. RAM'lardaki personelin üçte biri, rehber öğretmenlerin ise yarısı aileleri, okullardaki öğretmenleri ve yöneticileri kaynaştırma ve BEP konusunda yeterince bilgilendiremediklerini düşünmektedir (Güven ve Balat, 2006).

Değerlendirme süreci incelendiğinde özel eğitim alanlarının ve süreçlerinin tamamıma odaklanan çalışmalar olduğu gibi zihin yetersizliği olan, yaygın gelişimsel bozukluğu olan öğrencilere ya da sadece matematik alanına 
odaklanan araştırmalar görülmektedir. Bu araştırmaların bulguları doğrultusunda zihin yetersizliği olan veya yaygın gelişimsel bozukluğu olan öğrencilerin eğitsel değerlendirmelerinde işbirliği, erkenlik, bütünlük, yeterlilik, çeşitlilik ilkeleri istenilen düzeyde gerçekleştirilememektedir. İsteklilik ve gizlilik ilkeleri ise tam olarak yerine getirilmektedir (Marakl1, 2016). Matematik başarısına ilişkin yapılan bir araştırmada ailelerin süreçten memnun kaldıkları aktarılmaktadır (Türkkal, 2018). Değerlendirme sonrası oluşturulan programların sıklıkla çocuklardaki matematik başarısını arttırdığı görülmüş̧ür. Ek olarak ailelerin değerlendirmelerde kullanılan teknik ve araçlar hakkında ya da çocuğun devam edeceği özel eğitim süreci ile ilgili bilgi sahibi olmadığı aktarılmaktadır. Aileler RAM'lardaki değerlendirme süresini yeterli bulurken (Türkkal, 2018), RAM çalışanları açısından değerlendirme süreleri kısa, değerlendirme sayıları ise azdır (Yanık ve Gürgür, 2017; Yılmaz, 2016). Diğer taraftan değerlendirmelerde bireylerin sosyal çevresinin, yaşanılan yer ve ortamın dikkate alınmadığı vurgulanmaktadır (Avcıoğlu, 2012). Benzer şekilde değerlendirme stillerine odaklanılan bir araştırmada bazı RAM çalışanları test puanlarını test sonucu dışında bir bilgi kullanmadan yorumlamıştır. Diğer çalışanlar ise kendi gözlemlerini, hastane raporunu veya aileden toplanan aileyle ya da bireyle ilgili ekonomik durum, doğum geçmişi gibi bilgileri kullandıkları tespit edilmiştir (Börkan ve ark., 2017).

RAM süreçleri ana temasının son alt teması olan izleme sürecine ilişkin tüm çalışmalarda benzer bulgulara ulaşılmaktadır. Bu bulgu ise izleme çalışmalarının yetersiz olduğu (Yılmaz, 2016; Yurtsever, 2013) ya da hiç yapılmadığı yönündedir (Güven ve Balat, 2006; Kamen-Akkoyun. 2007). Dolayısıyla RAM'ın görev tanımı kapsamında izleme sürecini gerektiği gibi yürütmediği, bu çalışmaların aileler ve öğretmenlerin kontrolüne bırakıldığı görülmektedir (Özak, Vural ve Avcıoğlu, 2008).

\section{Demografik Özellikler}

Demografik özellikler teması altında idareciler, öğretmenler ve aileler olmak üzere üç alt temaya ulaşılmıştır. Bu paydaşların demografik özelliklerinin RAM süreçlerine etkisi incelenmiştir.

RAM müdürleriyle yapılan çalışmalarda cinsiyete, çalışma konumlarına, kıdemlerine, mezun olunan lisans programına, asil ya da vekil olarak görev yapmalarına, hizmet içi eğitime alınmalarına, yaşlarına, eğitim durumlarına (lisansüstï) göre anlamlı bir fark bulunamamıştır (Aydın, 2009; Tiryakioğlu, 2009). 
Benzer bulgular RAM'da görev yapan öğretmenler için de geçerlidir. Öğretmenlerin, cinsiyete, çalışma konumlarına, branşlarına, eğitim durumlarına (lisansüstü), kıdemlerine, yaşlarına göre anlamlı bir fark bulunamamıştır. Ek olarak hizmet içi eğitim alma, özel eğitim öğrencisiyle çalışma, özel eğitim dersi alma, ailede özel eğitim gereksinimi olan birey olma durumlarına göre de fark anlamlı değildir (Aydın, 2009). Ancak zıt bulguların olduğu araştırmalarda görülmektedir. Ailede engelli bireyin olma durumuna göre, rehberlik ve psikolojik danışmanlık ile diğer bölümlerden mezun olan öğretmenler arasında özel eğitim öz yeterliliğinde anlamlı fark bulunmuştur. Diğer bölümlerden mezun olup rehber öğretmenlik yapanlar, PDR mezunu öğretmenlere göre daha yüksek puana sahiptir (Gürbüz ve Bozgeyikli, 2014). Aynı çalışmada öz yeterliliği en yüksek grup 16-20 yıl mesleki deneyim, sonra 11-15 ve öz yeterlilikleri en düşük grup 6-10 yıl mesleki deneyimi olan gruptur. Ek olarak k1demi 1-5 y1l olanlarla 16-20 y1l olanlar arasında ve 6-10 y1l ile 16-20 y1l olanlar arasında özel eğitimde öz yeterliliklerine ilişkin mesleki deneyimi 1620 yıl olan grup lehine anlamlı fark bulunmuştur (Gürbüz ve Bozgeyikli, 2014). RAM'da çalışan öğretmenlerin okullarda çalışanlardan daha az güçlükle karşılaştıkları da aktarılmaktadır (Tike-Bafra ve Kargın, 2009).

\section{Sorunlar}

Son bulgu kümesi olan sorunlar teması altında, aileler, RAM personeli, bütçe, iş birliği, formlar/testler, kurum işleyişi ve fiziki şartlar olmak üzere yedi alt temaya ulaşılmıştır.

Ailelerin söz hakkının tanı, değerlendirme ve yerleştirme süreçlerinde kısıtlı olduğu belirtilmektedir (Özak, Vural ve Avcıŏlu, 2008). Ancak birçok araştırmada bu bulguya zit şekilde ailelerin son karar mercii olduğu ve çocuklarına ilişkin görüşlerinin önemli olduğu aktarılmıştır (Türkkal, 2018; Yılmaz, 2016). Farklı bir bakış açısı olarak ise, ailelerin RAM süreçlerine tam katılımında problemler olduğu ortaya konmuştur (Avcıoğlu, 2012; Yanık ve Gürgür, 2017). Karar merhalesinde aileler ile iş birliği yapılmaktadır ancak aileler çocuklarının akademik, psiko-sosyal gelişimi, sağlık durumu, eğitsel tanılama ve değerlendirme süreci hakkında yetersiz bilgiye sahiptir (Çakmak, 2017; Kamen-Akkoyun, 2007; Türkkal, 2018; Yurtsever, 2013). Bu eksikliğin ise öğretmenler tarafından yüz yüze ya da evrak aracılığıyla bilgilendirmeler yoluyla giderilmeye çalışıldığı ifade edilmektedir (Kamen-Akkoyun, 2007). Ancak yine aksi yönde görüş olarak ailelerin rapor bitimlerinde ve tanı sonrası yeterince bilgilendirilmediği de aktarılmaktadır (Avcıŏlu, 2012; Tiryakioğlu, 
2009). Araştırmalarda görülen son sorun ise özel rehabilitasyon merkezlerinden faydalanmak üzere maddi destek almak isteyen engelli bireylerin ailelerinin, testi alan bireyi testten düşük puan alması için yönlendirmesidir (Börkan ve ark., 2017; Y1lmaz, 2016).

RAM'larda yeterli uzman personelin olmadığ 1 (Güven ve Balat, 2006; Ekim, 2015; Kamen-Akkoyun, 2007; Tiryakioğlu, 2009; Yurtsever, 2013) ve değerlendirme sürecinde uyguladıkları testler hakkında eğitim almadıkları belirtilmektedir (Börkan ve ark., 2017; Yurtsever, 2013). Ancak personel say1sını dengelemek için sertifika ya da kurslarla farklı bölümlerden özel eğitime geçişin tartışılması gerektiği vurgulanmıştır. Ayrıca çalışan personelin şartlarının iyileştirilmesi gerektiği, RAM çalışanları ve rehber öğretmenlere özel eğitim alanına ilişkin akademik destek sağlanması, üniversitelerde bölümlerin sayısının arttırılarak öğrenci sayısının da arttırılması gerektiği ifade edilmiştir (Güven ve Balat; 2006; Özak, Vural ve Avcıoğlu, 2008). Ek olarak resmi yazışma, arşivleme gibi işlerden sorumlu memurlara ihtiyaç duyulduğu aktarılmaktadır (Yurtsever, 2013).

Bütçe alt temasına ilişkin sorunlar incelendiğinde birincil ihtiyacın değerlendirme ve izleme faaliyetlerinin rahatça yürütülebilmesi için RAM'ın hizmetine tahsis edilmesi talep edilen bir araç ihtiyacı olduğu görülmektedir (Kamen-Akkoyun, 2007; Yılmaz, 2016). Ek olarak okullar tarafından talep edildiğinde destek özel eğitim faaliyetleri verildiği ancak bu faaliyetlerin ne RAM ne de okul personelleri için ek ders ücreti kapsamında olmaması nedeniyle istenilen düzeyde gerçekleştirilemediği ortaya konmuştur (Kamen-Akkoyun, 2007; Özak, Vural ve Avcıŏlu, 2008).

Hastaneler ve RAM arasında iş birliği olmadığı görülmektedir (Çakmak 2017; Marakl1, 2016; Tiryakioğlu, 2009; Tükkal, 2018; Y1lmaz 2016; Yurtsever, 2013). Hastane dişındaki okul ya da öğretmenler gibi kurum ve kişiler arasında da iletişimin sağlıklı bir şekilde yürütülmediği görülmektedir (Güven ve Balat, 2006; Özak, Vural ve Avcığlu, 2008; Türkkal, 2018; Yurtsever, 2013). Ancak bu bulguya zıt olarak RAM dışındaki kurumlarla işbirliği yapı1dığı aktarılmıştır (Ekim, 2015). Kurum içi iletişim ve işbirliğine incelendiğinde de farklı bulgular dikkat çekmektedir. Kurum içi iletişim ve iş birliğinde herhangi bir sorun olmadığını belirten çalışmaların (Yurtsever, 2013) yanında, iş birliğinin yeterli düzeyde yerine getirilmediğini aktaran çalışmalar da (Maraklı, 2016; Yanık ve Gürgür, 2017) bulunmaktadır.

Araştırmalar değerlendirme açısından incelendiğinde, değerlendirme 
formlarının günümüz koşullarına uygun olmaması, ayırt ediciliğinin düşük ve yetersiz olması, geliştirme-uyarlama çalışmalarının yetersiz olması, uygulamaya dönük hizmet içi eğitimlerin yapılmaması, formların eski ve eksik olması değerlendirmeyi yapan kişiye göre değişen bir norm değer üzerinden yapılması, formların sayısının yetersiz olması, öğrencilerin psiko-sosyal açıdan uygulamaya hazır olmaması, öğrencilere yeterli süre ayrılmaması, değerlendirmenin ilk defa girilen bir ortamda tanınmayan kişiler tarafından yapılması değerlendirmede sorunların yaşanmasına neden olduğunu ortaya koymaktadır (Avcıoğlu, 2012; Çakmak, 2017; Özak, Vural ve Avcıoğlu, 2008; Türkkal, 2018; Y1lmaz, 2016; Yurtsever, 2013). Ek olarak öğrencinin cevapları ezberlemesi, test maddelerini rastgele işaretlemesi, bilerek yanlış cevap vermesi, teste aşina olması gibi durumların az da olsa yaşandığı görülmektedir (Yurtsever, 2013). Ayrıca değerlendirme formlarının yetersizlik düzeylerine göre hafif-orta-ağır olarak ayrıldığı, davranış problemlerine ve sosyal becerilere yönelik amaçlar içermediği, 0-6 yaş aralığındaki çocuklar ve lise çağındaki öğrenciler için amaçların yetersiz olduğu, görsel destek modüllerinin etkin olarak kullanılamadığı belirtilmektedir (Maraklı, 2016; Yılmaz, 2016). Tüm bu bulguların aksine alanyazında ölçme araçlarının öğrencilerin tam performansını ortaya koyabildiğini aktaran çalışma da yer almaktadır (Yanık ve Gürgür, 2017).

Kurum işleyişi incelendiğinde RAM'ların bağlı olduğu üst makamlardan yeterli düzeyde danışmanlık ve yardım alamadığı aktarılmaktadır (Ekim, 2015; Tiryakioğlu, 2009). Kurumun niteliği gözlem ve sözel geribildirimle değerlendirilmektedir (Ekim, 2015). Değerlendirme için gelen başvurularda eksik evrak getirilmesi, kurumun kapasitesinin aşan sayılarda başvuru olması nedeniyle ileri tarihlere randevu verilmesi, eğitim kurumlarından gelen bilgilerin yüzeysel, eksik ya da yanlış doldurulmuş olması gibi sorunlarla karşılaş1maktadır (Y1lmaz, 2016; Yurtsever, 2013). RAM'ların grup rehberliği, ölçme araçlarının geliştirilmesi, araştırma ve yayın gibi uygulama alanlarında aktif olmadığı aktarılmaktadır (Ekim, 2015). Ek olarak, RAM'lar tarafindan hizmet verdikleri bölgede özel eğitim alan çocuk, öğrenci ya da bireylere ilişkin hiçbir istatistik tutulmamaktadır (Çakmak, 2017).

RAM'larda yürütülen araştırmaların bulguları incelendiğinde en sık rastlanan sorunların fiziki şartlara ilişkin olduğu görülmektedir. Bu sorunlar arasında kurumun fiziki şartlarının engel türlerine göre düzenlenmeyişi, kurumun bağımsız binası olmayışı, personele ait oda yetersizliği, 
toplant1/konferans odası olmayışı, binanın çok katlı olup asansör bulunmaması, hissedilebilir zemin olmaması, sesli anons sistemi olmaması şeklinde sıralanmaktadır. Test/görüşme odalarında ise ses yalıtımının eksikliği, oda sayının yetersizliği, alanın küçük olması, uygun olmayan 1sı koşulları gibi eksikler bulunmaktadır (Avcıoğlu, 2012; Börkan ve ark., 2017; Çakmak, 2017; Ekim, 2015; Marakl1, 2016; Tiryakioğlu, 2009; Yılmaz, 2016; Yurtsever, 2013). Değerlendirme sürecinde kullanılmak üzere tüm RAM'larda benzer materyallerin kullanılabileceği bir standart oluşturulması (Çakmak, 2017), araç gereç ve materyal teminin sağlanması ya da yenilenmesi gerektiği ifade edilmektedir (Güven ve Balat, 2006; Yılmaz, 2016). Ancak, bu bulguya zit şekilde RAM çalışanlarının kullandıkları araç gereçleri (göster-yap, kağıt-kalem) yeterli buldukları çalışmaya da rastlanmaktadır (Türkkal, 2018). Ek olarak RAM çalışanlarına göre kaynaştırma uygulamaları yürüten okulların fiziksel koşullarının iyileştirilmesi (materyal, sınıf içi koşullar, kaynak oda vb.), sınıf mevcutlarının düşürülmesi gerekmektedir (Güven ve Balat, 2006; Kamen-Akkoyun, 2007; Özak, Vural ve Avcıoğlu, 2008).

\section{Tartışma, Sonuç ve Öneriler}

RAM'larda özel eğitim ile ilgili araştırmalar incelendiğinde 16 çalışmaya ulaşılmakta ve bu çalışmaların 2006-2018 yılları arasında gerçekleştiği görülmektedir. Yıllara göre dağılım dikkate alındığında 2015 sonrası yedi, 2010-2015 arası üç ve 2010 öncesi altı çalışma yapıldığı anlaşılmaktadır. Uzun yıllardır özel eğitim sürecinin işleyişinde temel kurumlardan biri olan RAM'larda yürütülen çalışmaların son yıllarda artış gösterdiği ifade edilebilir.

RAM'larda özel eğitimle ilgili araştırmalar katılımcılarına göre incelendiğinde tamamına yakınının (13) öğretmenlerle gerçekleştiği görülmektedir. Bu katılımcıların çoğunluğu özel eğitim, kalanı ise rehber öğretmelerden oluşmaktadır. Öğretmenlere nazaran daha az sayıda çalışmada (3) ise RAM idarecilerine yer verilmiştir. İdareci ve öğretmenlerin katılımcı olarak birlikte yer aldığı çalışmalar (2) da bulunmaktadır. RAM dışındaki paydaşların çalışmalara katılımı incelendiğinde ise okulda görev yapan öğretmenlerin dört, ailelerin ise iki çalışmada yer aldıkları görülmektedir. Ancak sağlık kuruluşlarındaki uzmanlar ve rehabilitasyon merkezleri çalışanları gibi diğer özel eğitim paydaşlarının araştırmalarda hiç yer almadığı görülmektedir.

Araştırmalar amaçlarına göre incelendiğinde sıklıkla fiziksel sorunlar, ölçme ve değerlendirme araçlarının kullanımı, paydaşlarla işbirliği, aile katılımı, RAM'ların genel işleyişi ve tanı, değerlendirme, yönlendirme, 
yerleştirme süreçleriyle ilgili sorunlar ortaya konmuştur. Bu amaçların dışında RAM'ların kaynaştırma uygulamaları ve BEP'lere ilişkin görev ve sorumluluklarının ele alındığı daha az çalışma bulunmaktadır. Ek olarak yaygın gelişimsel bozukluk ve öğrenme güçlüğü gibi yetersizlik türlerine yönelik RAM'lardaki mevcut işleyişin incelendiği çalışmalar görülmektedir. Birkaç nicel çalışmada ise RAM çalışanlarının demografik özelliklerinin RAM süreçlerine etkisi incelenmiştir.

Araştırmalarda kullanılan yöntemler incelendiğinde tamamının betimsel yöntemlerle gerçekleştirildiği görülmektedir. Nicel ya da nitel araştırma yöntemlerin eşit sayıda tercih edildiği görülmektedir. Bir çalışmada karma yöntem bir çalışma da ise karma olmaksızın nicel araç ve nitel teknikler bir arada kullanılmıştır. Betimsel araştırmalar RAM'lardaki mevcut durumu ortaya koyarak, işleyişi anlamaya yardımcı olsa da deneysel ya da ilişkisel çalışmaların eksikliği dikkat çekmektedir.

Araştırmalar bulguları açısından incelendiğinde ise RAM'larda materyal eksikliği, değerlendirme odalarının kullanışı olmaması, binaların yetersizlik türlerine göre dizayn edilmeyişi, 1sı, 1şık, yalıtımın uygun olmayışı gibi birçok fiziksel sorun görülmektedir. Ek olarak tüm yetersizlik türlerinin değerlendirmelerinde kullanılan formların ihtiyacı karşılamadığı ve güncellenmesi gerektiği, bütçe eksikliği, personel yetersizliği, yanlış ya da eksik evrakla başvuru yapıldı̆̆ 1 , özel eğitim sürecinde yer alan diğer kurum ve kuruluşlarla işbirliğinin gerçekleştirilemediği, aile katılımının tam olarak sağlanamadığ da aktarılmaktadır. Ayrıca BEP ve kaynaştırma uygulamalarına ilişkin RAM çalışanlarının yeterli bilgiye sahip olduğu ancak okullara bu konuda yeterince destek olunamadığ 1 bulgularına ulaşılmıştır. Çalışmaların çoğunda tanı, değerlendirme, yönlendirme, yerleştirme ve izleme süreçleri açısından, idareciler dahil tüm RAM çalışanlarının cinsiyet, çalışma konumları, kıdem, mezun olunan lisans programı, asil ya da vekil olarak görev yapmaları, hizmet içi eğitim almaları, yaşları, eğitim durumlarına (lisansüstü) göre anlamlı bir fark bulunamamıștır.

RAM'ların Rehberlik Hizmetleri Yönetmeliği (2017) ile verilen tarama, eğitsel tanılama, izleme, değerlendirme ve yerleştirme işlevlerini yerine getirilebilmesi için var olan sorunların çözülmesi gerekmektedir. Bu bağlamda; RAM'ların fiziksel şartlarının iyileştirilmesi, personel eksikliklerinin giderilmesi, güncel geçerlik ve güvenirlik çalışmaları gerçekleştirilmiş ölçme ve değerlendirme araçlarının sağlanması, paydaşlar arası işbirliği geliştirme 
çalışmaları yapılarak paydaşların aktif katılımının sağlanması ve RAM personeline gereksinimleri doğrultusunda hiçmetiçi eğitimler düzenlenmesi önerilebilir.

Özetle, ülkemizde özel eğitim sürecinin işleyişinde önemli bir yeri olan RAM'lara ilişkin farklı çalışmalar bulunmaktadır. Çalışma sayıları sınırlı olsa da genellikle benzer sorunlara işaret etmektedir. Dolayısıyla bu bulgular 1ş1ğında sorunların çözümüne, eksikliklerin giderilmesine yardımcı olacak, sisteme doğrudan müdahale etmeyi amaçlayan, uygulama içeren yeni çalışmalara ihtiyaç vardır.

$\mathrm{Bu}$ araştırma RAM'larda özel eğitimle ilgili yapılmış çalışmalara dair önemli verileri bir arada sunmakla birlikte bazı sınırlılıklara sahiptir. Seçilen araştırmalar sadece RAM'ların özel eğitim bölümleriyle ilgili olan ve RAM çalışanlarından katılımcıların dahil edildiği çalışmalardır. Gözden geçirme çalışmaları için belirlenen inceleme ölçütleri, nesnellikten uzaklaşmaya sebep olabilir ve genel olarak çalışmaların ana hatlarına ilişkin bilgi verir (Kavale, 2001). Dolayısıyla bu çalışmada inceleme ölçütleri doğrultusunda sınırlı veri akışı sağlamaktadır.

\section{Kaynakça}

Aslan, S. ve Bal, E. (2014). Rehberlik ve araştırma merkezlerinin örgütsel analizi. Eğitim ve Bilim, 39(174), 313-324.

Doi: 10.15390/EB.2014.1652

Avcıoğlu, H. (2012). Rehberlik ve araştırma merkez (RAM) müdürlerinin tanılama, yerleştirme-izleme, bireyselleştirilmiş eğitim programı (BEP) geliştirme ve kaynaştırma uygulamasında karşılaşılan sorunlara ilişkin algıları. Kuram ve Uygulamada Eğitim Bilimleri, 12(3), 2009-2031.

Doi: 10.17556/erziefd.402532

Aydın, E. (2009). Rehberlik ve araştırma merkezi yönetici ve ögretmenlerinin kaynaştırma eğitimine yönelik tutumlarının değerlendirilmesi (İstanbul ili örneği). Yayımlanmamış yüksek lisans tezi, Beykent Üniversitesi Sosyal Bilimler Enstitüsü.

Börkan, B., Öztemür, G., Yılmaz, O., Çetintaş, Ş., Gülcan, B. ve Özcan, M. (2017). Rehberlik ve araştırma merkezlerinde psikolojik test uygulama süreçleri. Türk Psikolojik Danışma ve Rehberlik Dergisi, 7(48), 161-185.

Ceyhan, E., Akdoğan, R. ve Bozkurt, F. (2013). Destek özel eğitim hizmetlerinin verimliliğinin araştırılması projesi (DESÖP). Ankara: Provizyon Prodüksiyon.

Creswell, J. W. (2013). Educational research: Planning, conducting, and evaluating quantitative. New Jersey: Upper Saddle River.

Çakmak, Z. (2017). Rehberlik ve araştırma merkezi personelinin öğrenme güçlüğ̈̈ olan bireylerin değgerlendirilme süreçlerine ilişkin görüşleri. Yayımlanmamış yüksek lisans tezi, Anadolu Üniversitesi Eğitim Bilimleri Enstitüsü.

Çuhadar, S. (2014). Özel eğitim süreci. S. Vuran, (Ed.), Özel ĕgitim içinde (3-30). 
Ankara: Maya Akademi.

Ekim, H. Ö. (2015). Rehberlik ve araştırma merkezlerinde yürütülen hizmetlerin incelenmesi: (İzmir ili örneği.). Yayımlanmamış yüksek lisans tezi, Ege Üniversitesi Sosyal Bilimler Enstitüsü.

Gürbüz, S. F. (2012). Rehberlik ve araştırma merkezlerinde çalışan rehber öğretmenlerin özel eğitimde rehberlik ve psikolojik danışmaya yönelik öz yeterlik alglları. Yayımlanmamış yüksek lisans tezi, Erciyes Üniversitesi Eğitim Bilimleri Enstitüsü.

Gürbüz, S. F. ve Bozgeyikli, H. (2014). Rehberlik ve araştırma merkezlerinde çalışan rehber öğretmenlerin özel eğitimde rehberlik ve psikolojik danışmaya yönelik öz yeterlik algıları. OPUS Uluslararası Toplum Araştırmaları Dergisi, 4(6), 79-99.

Gürsel, O. (2013). Özel eğitimde değerlendirme. İ. H. Diken, (Ed.), Özel eğitime gereksinimi olan ögrenciler ve özel eğitim içinde (31-58). Ankara: Pegem.

Güven, Y. ve Balat, G. (2006). Kaynaştırma uygulamalarına ilişkin rehber öğretmenler ve rehberlik araştırma merkezi çalışanlarının görüşleri. Marmara Üniversitesi Atatürk Ĕ̈itim Fakültesi Eğitim Bilimleri Dergisi, 24(24), 95-108.

Herdman, E. A. (2006). Derleme makale yazımında, konferans ve bildiri sunumu hazırlamada pratik bilgiler. Hemşirelikte Eğitim ve Araştırma Dergisi, 3(1), 2-4.

Kamen-Akkoyun, A. (2007). Rehberlik ve araştırma merkezi müdürlügü personelinin kaynaştırma eğitimine ilişskin görüşler. Yayımlanmamış yüksek lisans tezi, Abant İzzet Baysal Üniversitesi Sosyal Bilimler Enstitüsü.

Karaköse, B. ve Bozgeyikli, H. (2012). Örgütsel bağlılık ve çalışma yaşamı kalitesi arasındaki ilişki: rehberlik araştırma merkezlerinde çalışan personel üzerine bir çalışma. Hak Iş̧ Uluslararası Emek ve Toplum Dergisi, 1(2), 164-180.

Kavale, K. A. (2001). Decision-making in special education: The function of meta analysis. Exceptionality, 9(4), 245-268.

Doi: $10.1207 / \mathrm{S} 15327035 \mathrm{EX} 0904 \_6$

Maraklı, Ö. (2016). Rehberlik ve araştırma merkezlerinde çalışan özel eğitim öğretmenlerinin eğitsel değerlendirme ve yerleştirmeye bağlı olarak kullanılan modül programlarının uygulanması hakkındaki görü̈slerinin incelenmesi. Yayımlanmamış yüksek lisans tezi, Gazi Üniversitesi Eğitim Bilimleri Enstitüsü.

Özak, H., Vural, M. ve Avcioğlu, H. (2008). Rehberlik araştırma merkezi müdürlerinin gönderme tanılama yerleștirme izleme ve değerlendirmeye ilişkin görüş ve önerileri. Abant İzzet Baysal Üniversitesi Eğitim Fakültesi Dergisi, 8(1), 189206

Özgözgü, S. (2011). Rehberlik ve araştırma merkezlerinde örgüt kültürü. Batı Anadolu Ĕ̈itim Bilimleri Dergisi, 2(4), 27-48.

Rehberlik Hizmetleri Yönetmeliği. (10 Kasım 2017). T. C. Resmî Gazete, 1-112.

Tike-Bafra, L. ve Kargın, T. (2009). Sınıf öğretmenleri, rehber öğretmenler ve rehberlik araştırma merkezi çalışanlarının bireyselleştirilmiş eğitim programı hazırlama sürecine ilişkin tutumları ve bu süreçte karşılaştıkları güçlüklerin belirlenmesi. Kuram ve Uygulamada Ĕgitim Bilimleri, 9(4), 1933-1972.

Tiryakioğlu, Ö. (2009). Rehberlik ve araştırma merkezi müdürlerinin özel eğitim bölümünün sorunlarını algılamaları. Yayımlanmamış yüksek lisans tezi, Abant İzzet Baysal Üniversitesi Sosyal Bilimler Enstitüsü.

Türkkal, A. (2018). Matematik becerilerinde yetersizlik görülen ilkokul öğrencilerinin 
rehberlik ve araştırma merkezindeki eğitsel tanılama süreçlerinin incelenmesi. Yayımlanmamış yüksek lisans tezi, Yıldız Teknik Üniversitesi Sosyal Bilimler Enstitüsü.

Yanık, Ş. ve Gürgür, H. (2017). Procedures in Turkey for guiding students with special needs into inclusive settings. Educational Sciences: Theory \& Practice, 17(5), 1649-1673.

Doi: 10.12738/estp.2017.5.0066

Yılmaz, Y. (2016). Rehberlik ve araştırma merkezlerinde tant, değerlendirme ve izleme süreçlerinin incelenmesi: Iş̧itme kayıplı çocuklar örneği. Yayımlanmamış yüksek lisans tezi, Anadolu Üniversitesi Eğitim Bilimleri Enstitüsü.

Yurtsever, Ş. (2013). Ĕ̈itsel tanılama ve değerlendirme sürecinde görev alan rehberlik ve araştırma merkezi personelinin karılaştı̆̆ sorunların belirlenmesi. Yayımlanmamış yüksek lisans tezi, Marmara Üniversitesi Eğitim Bilimleri Enstitüsü. 